The emergence of Filipino values among forgiveness studies

Rungduin, Darwin C. $\bowtie$

Colegio de San Juan de Letran, Manila, Philippines (darwinrungduin@yahoo.com)

Rungduin, Teresita $\mathrm{T}$.

Philippine Normal University, Manila, Philippines (tessa_rungduin@yahoo.com)

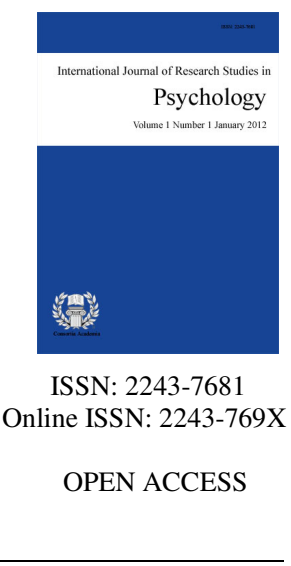

Received: 21 February 2013

Revised: 24 July 2013 DOI: $10.5861 /$ ijrsp.2013.367

Accepted: 20 August 2013

\title{
Abstract
}

This paper reviewed 6 forgiveness studies that were made to understand Filipino forgiveness behaviors. The aim was to extract general Filipino values as well as the cultural values that Enriquez proposed in his theory of kapwa. Using combined qualitative and quantitative approaches in the research reports of those studies, the values that were salient in the experience of forgiving a transgressor were identified. Results showed that certain personal (open-mindedness and understanding) and interpersonal (smooth interpersonal relationship and justice) characteristics become evident in forgiving another a transgressor. Likewise, loob-related values were recovered from the analysis. The value of freedom was contextualized in terms of its function in the forgiveness experience. Finally, a value-based forgiveness model was proposed based on the results.

Keywords: kapwa; forgiveness model; Filipino values; content analysis; loob 


\section{The emergence of Filipino values among forgiveness studies}

\section{Introduction}

Forgiveness has attracted a great amount of attention among psychologists in the past years (see McCullough \& Witvliet, 2002), examining it as a psychological construct rather as a religious and theological component of one's manifestation of faith or affiliation. Because of this, forgiveness has been examined both as a cause and an outcome. Particularly, a number of studies have looked into the role of forgiveness in future relationships (Tsang, McCullough, \& Fincham, 2006) either explaining dynamics of relationship with another person or explained by broader psychological processes such as of personality traits (Chiaramello, Sastre, \& Mullet, 2008; Fu, Watkins, \& Hui, 2004). The studies on forgiveness provided insights in terms of how people evaluate the importance of relationship with others, specifically when it comes to the desire to maintain it. The changes that McCullough and Witvliet (2002) enumerated that take place within the relationship after granting forgiveness provided more dynamics in terms of how forgiveness is being studied. These changes include internalization of justice and empathy (Karremans \& Van Lange, 2005; Wenzel \& Okimoto, 2010), improved sense of gratitude (Sandage and Williamson, 2010), and generous attributions on others' behaviors (McCullough, 2001). While forgiveness happens within the context of relationship, personality psychologists have also speculated the important role of personality disposition in seeking (Chiaramello, Sastre, \& Mullet, 2008) and in granting forgiveness (Berry, Worthington, O'Connor, Parrott, \& Wade, 2005; Thompson et al., 2005). Since there seem to have an association between forgiveness and personality traits, it is speculated that there are people who are most likely to forgive than others. In either of these conceptions of forgiveness, it is expected that in the process of forgiving other people, certain values emerge that could either be brought about by the cultural influences or one's disposition.

Forgiveness is a venue by which a person's values are actually challenged, especially those that are valued by one's cultural group (Ho \& Fung, 2011; Pan, 2008; Paz, Neto, Mullet, 2008). There are two perspectives form which values can be examined in the experience of forgiving others and being forgiven: (a) that of the person who has been transgressed and (b) the transgressor. The experience provides the opportunity for their value systems to be harmonized in order to achieve forgiveness. The harmonizing process requires identification of and subscription to one's set of values. At the same time, there is the process of synchronizing one's values with the other person. For instance, if one values honesty more than material possession like money, it is perhaps more difficult for this person to forgive another person who lies than a person who had robbed him/her. In this situation, the value (honesty) facilitates forgiving and becomes a ground for evaluating future transgressions. This proposition implies that forgiveness may not necessarily be a value but instead a product of value and a by-product of the combination of different values. During the process of both seeking and granting forgiveness, values can be evident because of its usefulness in determining actions that support forgiveness. When these values, in fact, become highly internalized, forgiveness can be habituated (Klatt \& Enright, 2009) and therefore values become integrated within the process.

The relationship between values (i.e. empathy and actualizing religious teaching, Williamson, 2007) and forgiveness can be clearly articulated but only a few had underwent emprical tests such as justice (Wenzel \& Okimoto, 2010; Klatt \& Enright, 2009; Karremans \& Van Lange, 2005; Exline, Worthington, \& Mccullough, 2003) and empathy (Sandage \& Worthington, 2010; Toussaint \& Webb, 2005). These values perhaps were given attention because of their immediate relationship in forgiving others. As Karremans and Van Lange (2005) found out, when values like justice and empathy are activiated, the propensity to forgive others increases. This argument has been advanced by Wenzel and Okimoto (2010) by arguing on the importance of examining the facilitative influence of forgiveness in restoring the value of justice.

The relationship between culture and values had been articulated in various literatures (Ho \& Fung, 2011; 
Enriquez V. G., 1978; Pe-Pua \& Protacio-Marcelino, 2000). Ho and Fung (2011) explained that those values that have been associated to a specific culture is assumed to affect people's way of thinking, emotional expressions, and conflict resolution. Forgiveness as a venue in solving conflicts could be affected by how a group of people may subscribe to and endorse a particular set of values. These values are generally activated when one is to evaluate the actions of a transgressor before, during, and after granting forgiveness. This is assumed to hold true to people who are seeking forgiveness. In the Filipino context, Enriquez (1978) postulated that the Filipino personality can be understood through the configuration of values that he or she identifies. Because these are cultural values, Enriquez explained that these may be central in the Filipinos' day-to-day interaction and they guide behaviors especially in social relationships which may include the seeking and granting of forgiveness. Because of the possible overlaps that exist between values and forgiveness, the latter can be examined and identified, that is, to analyze the values that surface in the course of forgiving others.

In the Kapwa theory of Enriquez $(1978 ; 1989)$ he catalogued indigenous Filipino values that are postulated to be central in the understanding of these values. He categorized the values into three major categories: the core, the pivotal interpersonal, and the surface values. The kapwa (shared identity) is considered as the core value to be overarching the three categories. Largely, this shared identity focuses on the high regards of Filipino towards relationship. It is clarified; however, that pakikipagkapwa (the act of sharing one's identity) is more than maintaining smooth interpersonal relationship (which is referred to as pakikisama). Kapwa is taking others as a fellow human being (Pe-Pua \& Protacio-Marcelino, 2000).The pivotal category serves as an important propelling agent in order to translate kapwa into a behavior. The pakikiramdam (shared inner perception) is the value under this category. Pakikiramdam is an act of sensing the situation, including the feelings and thoughts of others and an anticipation of action. This is important because it guides an individual's behavior in interacting with others. The third category, the surface values, is composed of several values that are readily utilized in most social interactions. These values are grouped as the colonial-accomodative surface values, the associated behavior pattern, and the confrontative surface values. The colonial-accomodative surface values is composed of hiya (propriety/dignity), utang na loob (depth of gratitude), and pakikisama (companionship). The associated behavior pattern, on the other hand, includes biro (joke), lambing (sweetness), tampo (affective disappointment). Lastly, the confrontative surface value include bahala na (determination), sama and lakas ng loob (resentment and guts), pakikibaka (resistance). This paper worked primarily in this set of values, although other values that emerged were also taken in a closer look.

In the context of cultural investigations, particularly in the Philippines, studies on forgiveness are considered very young. To date, very few studies have explored and tested the forgiveness behavior of Filipinos and how culture and personality are merged in this experience. The absence of conceptual and theoretical explanations on how Filipinos forgive, the identification of factors that contribute to arrive to forgive others, and how forgiveness may be related or different with indigenous tags related to forgiveness, like pagpapalampas (letting it pass) (Rungduin, 2012) were some of the pressing issues that forgiveness researchers are facing at this time. The attempt to develop a culture-based framework of forgiveness allow psychologists and those others who may be trying to maximize the utility of the concept in providing psychological services (i.e. forgiveness therapy) that are more suited to their clientele. This review of studies hopes to bring together the forgiveness studies that so far have been conducted involving Filipino experiences as their point of analysis. Values being a measure of cultural manifestation were identified with the intention of providing sound conceptual understanding of the phenomenon based on Filipino experiences.

\subsection{Research objectives}

The literature review involves the consolidation of researches that have been conducted with regard Filipino forgiveness behaviors. These researches were used to achieve the following objectives:

Describe the experiences of Filipinos in terms of forgiving others 
Identify the emerging Filipino values based on Enriquez's conceptualization of Filipino personality that become salient in the process of forgiveness.

\section{Methodology}

The study primarily aimed to provide an indigenous understanding of how the Filipino personality structure becomes more visible when one is confronted with situations that require forgiving. Despite the abundance of literature with regard forgiveness in the different international journals there seems to have a strong need to evaluate the construct in relation to Filipino experiences. This is not to discount the validity of the results of those studies; however, there is a rising need to decipher the Filipino's conceptualization of the relationship and the manner by which values are carried out during these interactions. Ultimately, the analysis aims to map out the variations in understanding the forgiveness behaviors.

\subsection{Methods}

In order to actualize the objectives of this review, a clarification of the concept of forgiveness was undertaken. The intention of this process is for ensuring that results are not confounded other related concepts. A key word search was done using the words "forgiveness" and the Filipino translation "pagpapatawad" were used in initially selecting materials to review.

\subsection{Searching for the literature}

There is a dearth of literature regarding the studies on the forgiveness behavior of Filipinos because the concept of forgiveness has not yet been deeply clarified with other psychological concepts (Rungduin, 2012). Other researches that explored other constructs which included forgiveness were not included, the main reason was that the constructs not may or may not be related to forgiveness may confound the intention of this literature review which is to clarify the construct in relation to the experiences of Filipinos. Studies that focused on conflict resolution, reconciliation, pardoning, condoning were particularly excluded in this report. Although they are associated with forgiveness, they are, however, normally conceptualized as by-products of granting forgiveness (Strelan, 2006).

What had been included in this review were researches that (1) made use of the experiences of Filipinos in either granting or seeking forgiveness with other people, (2) generated their impression based on empirical validation, (3) evaluated the process of forgiveness at the level of interpersonal relationships, and (4) studied forgiveness as a psychological construct. This is in contrast to researches that were found in the process of searching for literature that were focusing on aggregated data, such as Asian respondents, opinion-based and personal observations, societal and political viewpoints, and theological and religious perspectives were used to explain the phenomenon of forgiveness. If included, this would not provide elaboration on the forgiveness behaviors of Filipinos and instead create more misleading thoughts about it.

\subsection{Sources of materials to review}

Full copies of the researches were obtained and were considered candidates for the review. An exhaustive search was done using the EBSCO with regard published materials, on Filipino forgiveness behaviors were the key searches. In that search, one (1) (Worthington Jr. \& et.al, 2010) research report came out relevant and was used in the review. In terms of the printed and locally published articles, one (1) (Yabut, 2009) master's thesis was published in the Philippine Journal of Counseling Psychology and that version was used in this review. Large portions of this review were generally papers generated in obtaining a graduate degree (De Castro, 2008; Valbuena, 2009; Tabbada-Rungduin, 2011). Among the materials that were reviewed, two (2) were for the completion of their masters' degrees and one (1) for her doctorate degree. Most of them came from major universities in Metro Manila. One undergraduate cross-cultural research (Santos, 2012) from the U.S. was included in this review because of the comprehensiveness of the data obtained from his Filipino respondents and 
the amount of knowledge that it can provide with regard to Filipino forgiveness behavior. In total, six (6) materials were used in addressing the objectives of this paper. Some of these authors were personally approached in order to obtain full copies of their researches, especially those papers that were completed for graduate degrees.

\subsection{Analysis of materials}

There were two folds of analyses that were used in the studies that were included in this review.

\subsection{First level analysis.}

This level of analysis involved the description of studies that have been conducted regarding forgiveness. This provides the current state of research activities and the manner by which it is be

1 and conceptual grounding of forgiveness, or tested the durability of forgiveness as an approach to help ing approached by researchers. The nature of analysis was presented in terms of binary analysis. Although there seem to have few studies on forgiveness made in the Philippines, there seem to have a wide variation of approaches used in these studies. Thus it creates a wide space of continuum in comparing these researches. These binaries were described in two opposite approaches in the way forgiveness has been studied. The following binaries were used.

Conceptual development - intervention testing binary. This binary analyzed the primary interest of forgiveness researchers in terms of how the forgiveness construct was examined. It looked into whether studies on forgiveness were intended to conceptually clarify it, proposed a theoreticapeople in improving their psychological and interpersonal state.

Quantitative - qualitative binary. This binary defined the general approach in studying forgiveness, thus the level of analysis focused on the epistemological approach in studying the phenomenon. This evaluated the type of the primary data that was used which later became the basis of making conclusion in their studies.

Process - structure binary. This binary clarified the explanation of the research papers that were reviewed in terms of what actually constituted forgiveness. The process perspective highlighted the step-by-step procedures that people experience in arriving to forgive other people. On the other hand, structure researches focused on the identification and explanation of contributory factors that facilitated the experience of forgiving a transgressor.

\subsection{Second level analysis.}

This level of analysis focused on the highlights of the results and discussion of the six (6) researches that were reviewed in this paper. First, there was a free listing of the values that emerged in the results and discussions on the different materials that were reviewed. Similar values were combined based on the similarities of manifestations and, if provided, how it is defined and elaborated by the researchers. The second portion of this level of analysis is the comparison of the values identified by Enriquez (1994) in his conceptualization of kapwa. This analysis was done both at the level of general values (Surface, Pivot, and Core values) and specific values under each of these categories.

Value extraction process. The main data analyzed were the result and discussion portions of the different research materials involved in this review. Particularly, the interpretation and the model that the researchers proposed were subjected in the extraction of the values. The following values were identified by Enriquez (1978) in relation to his formulation of the Kapwa theory: pakikiramdam (shared inner perception), accommodative surface values composed of hiya, utang na loob, and pakikisama, associated values composed of biro, lambing, and tampo, and confrontative surface values composed of bahala na, sama/lakas ng loob, and pakikibaka. Aside from these values, Enriquez directly extended the concept of Kapwa with other Filipino values such as karangalan (dignity), kalayaan (freedom), and katarungan (justice). Aside from these general categories of 
Rungduin, D. C. \& Rungduin, T. T.

values, other values were also taken into account.

This was particularly done using a line-by-line analysis approach (Gibbs, 2007). This approach was done by reading through each line of the discussion then identifies a value that appeared to be evident in each line. This was done by 18 trained raters wherein three (3) were assigned for each of paper. The raters were oriented on the nature of the study as well as on the framework where the study is coming from. Part of their instructions was to identify the values in Filipino language so as to capture the essence of the values. Furthermore, they were encouraged to discuss the value labels and come up with an agreement of these values.

Consolidation of values. Values that were extracted in line-by-line analysis were verified and encoded. Verification is done by checking on the manner by which values were identified. Through this process, initial overlaps on the labels were identified and clarified. The values that were observed in this phase were encoded in the Yoshikoder; a software intended for content analysis. The software facilitated the identification of the frequency by which a value was observed. After this, the values were clustered according to the extent of similarities of the value labels.

\section{Results}

The six (6) research materials that were reviewed in this paper provided a general overview on the state of understanding forgiveness. Particularly, the premises and the general descriptions of these studies can later on set trends and directions on the study of forgiveness.

\subsection{First level analysis}

As mentioned, this provided a general description of the studies that had been conducted in the area of forgiveness. There were three binaries used as a point of analysis in this review. These were the (1) conceptual development vs. intervention testing, (2) quantitative vs. qualitative, and (3) process vs. structure. Table 1 presents the summary of the clusters.

\section{Table 1}

Binary analysis of Forgiveness Studies

\begin{tabular}{lll}
\multicolumn{1}{c}{$\begin{array}{c}\text { Conceptual development- } \\
\text { intervention testing }\end{array}$} & \multicolumn{1}{c}{ Quantitative-qualitative } & \multicolumn{1}{c}{ Process- structure } \\
\hline $\begin{array}{l}\text { Conceptual Development:(4) } \\
\text { Valbuena (2009) }\end{array}$ & Qualitative:(3) & Process:(3) \\
Yabut (2009) & Valbuena (2009) & Valbuena (2009) \\
Tabbada-Rungduin (2011) & Yabut (2009) & Yabut (2009) \\
Santos (2012) & Tabbada-Rungduin (2011) & Tabbada-Rungduin (2011) \\
& & \\
\hline Intervention Testing:(2) & Quantitative:(3) & Structure:(4) \\
De Castro (2009) & De Castro (2009) & De Castro (2009) \\
Worthington, Jr., et.al (2010) & Worthington, Jr., et.al (2010) & Worthington, Jr., et.al (2010) \\
& Santos (2012) & Tabbada-Rungduin (2011) \\
& & Santos (2012) \\
\hline
\end{tabular}

\subsection{Conceptual development - intervention testing binary}

It can be identified that majority of the studies that initially explored Filipino forgiveness behaviors were intended to understand the dynamics of forgiveness. Particularly, these studies (Yabut, 2009; Valbuena, 2009) attempted to examine the indigenous dimensions of forgiveness. Valbuena's (2009) conception of forgiveness was anchored on the indigenous concept of pagdadala of Decenteceo. She believed that forgiveness could not be an equivalent of pagpapatawad. For her, these two concepts follow different premises that can be rooted in the 
specific behavioral cues and their linguistic loadings. Yabut (2009), on the other hand, provided an insight on what people experience when they are forgiving other people. He identified five major descriptions of people's experiences in forgiving others. These descriptions were op nness, understanding the experiences, acceptance, liberation, and new perception of the relationship. In the study of Tabbada-Rungduin (2011), forgiveness was described in the context of developmental comparisons. In her findings, she saw a significant similar pattern in terms of the experience in forgiving others across the life span. Forgiveness emerges, in her findings, as a desire to resolve an interpersonal transgression. In these three studies, both Valbuena (2009) and Tabbada-Rungduin (2011) provided frameworks that describe the experience of forgiving people. Santos (2012), in his comparison of U.S. and Filipino sample provided support to some of the preconceived differences between Americans and Filipinos due to the diverse cultural orientations. Although he admitted that only marginal differences can be observed between the two, these differences can be attributed to the religious belief of Filipinos and the desire to save one's face and communal motives. Because of these findings, he inferred that the propensity to forgive others can be observed in the Filipino than the U.S. samples.

It also became evident that some studies explored the possibility of using forgiveness as an intervention in the counseling process. These attempts were evident in the studies of De Castro (2009) and Worthington (2010). Aside from the propensity to forgive and the actual forgiveness behavior, De Castro (2009) also evaluated the group forgiveness intervention in reducing the stress of high school students. She hypothesized that group forgiveness intervention can reduce the stress experiences of her sample and there would be an increase in their propensity to forgive and the actual granting of forgiveness. Her study, however, did not confirm this moderating function of forgiveness. Worthington (2010), on the other hand, tested his REACH (Recall the hurt, Emphatize with the one who hurt them, offer an Altruistic gift for forgiveness, make a commitment to forgive, and Hold on to the forgiveness) model of psychoeducational intervention. Their group particularly tested the model side-by-side with the Christian religious affiliation of Filipinos as their cultural marker. Their findings provided support in Worthington's assumption that his model of psychoeducational intervention is adaptive in different cultures, as it has already been tested with the U.S. sample.

\subsection{Qualitative vs. quantitative binary}

The nature of the source of data in inferring to the forgiveness behavior of Filipino reflects the epistemological belief on the concept of forgiveness. Qualitative studies mostly, but not all, reside on the idea that the phenomenon of interests, such as forgiveness, can be constructed as unique to an individual or group of individuals because of the varying experiences that greatly contribute to it. The quantitative approaches, on the other hand, reside on hypothesis testing and the possible generalization of the finding to a large group of people, without so much taking into account the nature of experiences that give context to one's behavior. The qualitative approach was the premise that the researches of Yabut (2009), Tabbada-Rungduin (2011), and Valbuena (2009) came from. Yabut (2009) made use of phenomenology in his research following a careful analysis of describing forgiveness in the realm of the experiences of the participants. Tabbada-Rungduin, on the other hand, used the grounded-research theory as her design and collected and analyzed the forgiveness experiences of using life narratives theory of personality of McAdams. Lastly, Valbuena (2009) largely relied on the results of her interviews in the integration of pagpapawatad with the pagdadala (the manner of carrying an experience) model of Decenteceo.

In terms of the quantitative orientation, De Castro (2009) and Worthington, Jr. et. al's (2010) made used of experimental approach in order to test the feasibility of using the forgiveness as an intervention. In terms of De Castro's experiment, she measured forgiveness using Forgiveness Scale by Rye et. al. (2001) which consists of 15 items using 5 point likert as the basis of subject's responses. The instrument that she used is consisted of two (2) general subscales, these are the Absence of Negative (AN) thoughts, feelings and behaviors towards the transgressor and the Presence of Positive (PP) thoughts, feelings, and behaviors towards the transgressor. Along with this instrument was the use of Forgiveness Efficacy Scale (author of the instrument was not indicated) in order to determine the difference between the person's level of actual forgiveness and the confidence to 
perform specific forgiveness-related tasks. Worthington, Jr., et. al (2010), on the other hand, measured forgiveness with Trait Forgiveness Scale by Berry et. al. (2005); which measures the disposition of the person to forgive an interpersonal transgression over time across situations. This scale is consists of 10 items. Another instrument that they used was the Transgression-related Interpersonal Motivations Inventory (TRIM; McCullough, et. al., 1998). The 12-item instrument intends to measure the unforgiving motivations of the participants of the experiment. This measures Avoidance (TRIM-A) and Revenge (TRIM-R) motivation towards the transgressor. Lastly, they made use of the Single-Item Forgiveness Scale (SIF; Berry, Worthington, Parrott, O'Cannor, \& Wade, 2001) to assess the degree to which participants have forgiven a specific transgression. Similar to Worthington, Jr., et. al.'s (2010) instrument, Santo also made use of the TRIM as his measure of forgiveness with very strong similarities of inter-item consistencies between Filipino and American samples in the two subscales of the instrument.

\subsection{Process-Structure Binary}

This binary describes the manner by which forgiveness was studied, that is either the study intended to describe the process by which a person experiences how to forgive or the identification of the factors that constitute or contribute to forgiveness. The process studies also provided a model that described and explained the experiences during transgression and how it becomes relevant in forgiving others. Among the studies that were reviewed, it is the study of Tabbada-Rungduin (2011) that is considered to examine forgiveness both at the level of process and structure. Her study is considered as focusing on the process in the context of how she gathered her data. Primarily, she asked her respondents to describe the experience of forgiving others in terms of the beginning (pinagmulan), experience (pinagdaanan), and the outcome (kinahinatnan). The life stories that were shared by her respondents were later consolidated using these three categories. Using the data that she obtained, she came up with a model that focuses on the structures of forgiveness experience. In her model, she specifically describes the forgiveness experience in three domains: the pag-iisip (cognitive), the pakikiramdam (affective), and the pag-uugali (behavioral).

In Valbuena's (2009) study, she explained that forgiveness is determined by the nature of relationship and the transgression of experience highlighted what actually happened (pangyayari) and what was felt (pakikiramdam). The model further explains that people who intend to forgive others will go through fixing the relationship (pagsasaayos). The fixing process, however, may not always lead to continuing with the relationship, instead, one could also have an option to relinquish the relationship, depending on how the person is taking the transgression that is either to simply accept or let go of the experience. Although Yabut (2009) identified the essences of forgiveness, he inferred these as part of the dynamic process of forgiveness. Expectedly, several changes are supposed to take place within the person and the relationship as one undergoes in the stages involved in forgiving others. Also, in the process of forgiving others, behavioral, affective, and cognitive aspects are covered by the changes that Yabut (2009) identified.

The studies of De Castro (2009), Worthington, Jr. (2010), and Santos (2012)were considered structure studies since they did not intend to study forgiveness in the context of identifying the specific experiences of Filipinos in forgiving others; instead their studies were focused on analyzing the contribution of different factors in the forgiving in general. De Castro (2009), for example, examined forgiveness in the context of stress reduction mechanism disregarding the contextual experience of the person in forgiving others. This is almost the same in the study of Worthington et al. where in a psychoeducational program was tested in reducing unforgiving motivation of their participants. In both studies, forgiveness was used as an independent variable. While those previous studies examine the impact of forgiveness on their dependent variables, Santos (2012), on the other hand, looked at the correlation of different cultural and motivational variables with the propensity to forgive. He particularly included the following variables: cultural values, religiosity, relationship satisfaction, positive and negative emotions, and interpersonal motives. 


\section{The Filipino experience in forgiving others}

This level of analysis does not only intend to identify the values that are relevant in forgiving other people but also to describe the experience itself. This analysis is divided into four general categories: description of the transgression experienced, characterization of the process in forgiving others, outcomes of forgiveness, factors that contribute in forgiving others. Tables 2 and 3 present the summary of the results of the frequency count of the occurrence of these categories.

Table 2

Description of forgiveness experience of Filipinos

\begin{tabular}{|c|c|c|c|c|c|}
\hline \multicolumn{2}{|c|}{ Description of Transgression } & \multirow{2}{*}{$\begin{array}{l}\text { While in the } \\
\text { Forgiveness } \\
\text { Description }\end{array}$} & \multirow{2}{*}{$\begin{array}{c}\text { Process of } \\
\text { Frequency }\end{array}$} & \multicolumn{2}{|c|}{ Outcomes of Forgiveness } \\
\hline Description & Frequency & & & Description & Frequency \\
\hline Egocentrism & 3 & Pag-asa (Hope) & 4 & $\begin{array}{l}\text { Pagbitaw (Letting } \\
\text { go) }\end{array}$ & 4 \\
\hline $\begin{array}{l}\text { Pagpapakitang-tao } \\
\text { (Impression-making) }\end{array}$ & 2 & $\begin{array}{l}\text { Pagganti } \\
\text { (Revenge) }\end{array}$ & 3 & $\begin{array}{l}\text { Pagsasaayos } \\
\text { (To fix) }\end{array}$ & 2 \\
\hline Pananakit (Hurting) & 2 & $\begin{array}{l}\text { Pag-iwas } \\
\text { (To avoid) }\end{array}$ & 3 & $\begin{array}{l}\text { Pagbabati } \\
\text { (to reconcile) }\end{array}$ & 1 \\
\hline $\begin{array}{l}\text { Pagbabalewala (Not } \\
\text { to be appreciated) }\end{array}$ & 1 & $\begin{array}{l}\text { Pursigido } \\
\text { (Diligence) }\end{array}$ & 3 & $\begin{array}{l}\text { Pagbabago } \\
\text { (To change) }\end{array}$ & 1 \\
\hline $\begin{array}{l}\text { Dominante } \\
\text { (To dominate) }\end{array}$ & 1 & $\begin{array}{l}\text { Pagtitimbang } \\
\text { (To evaluate) }\end{array}$ & 1 & $\begin{array}{l}\text { Pagpapalaya } \\
\text { (Setting free) }\end{array}$ & 1 \\
\hline $\begin{array}{l}\text { Di-pagsang-ayon } \\
\text { (To disagree with) }\end{array}$ & 1 & $\begin{array}{l}\text { Kagustuhan } \\
\text { (Desire) }\end{array}$ & 1 & $\begin{array}{l}\text { Panghihinayang } \\
\text { (To regret) }\end{array}$ & 1 \\
\hline $\begin{array}{l}\text { Pagkamakasarili } \\
\text { (Being selfish) }\end{array}$ & 1 & Bigat (Weight) & 1 & $\begin{array}{l}\text { Kuntento } \\
\text { (Contentment) }\end{array}$ & 1 \\
\hline $\begin{array}{l}\text { Pagbintang } \\
\text { (Be accused of) }\end{array}$ & 1 & & & & \\
\hline $\begin{array}{l}\text { Paghuhusga } \\
\text { (Be judged as) }\end{array}$ & 1 & & & & \\
\hline
\end{tabular}

\section{Table 3}

Contributory factors in forgiving others

\begin{tabular}{|c|c|c|c|c|c|}
\hline \multicolumn{2}{|c|}{ Cognitive-based } & \multicolumn{2}{|c|}{ Affective-based } & \multicolumn{2}{|c|}{ Behavior-based } \\
\hline Description & Frequency & Description & Frequency & Description & Frequency \\
\hline $\begin{array}{l}\text { Pagkabukas ng isip } \\
\text { (Opening one's mind) }\end{array}$ & 16 & $\begin{array}{l}\text { Pagkamaawain } \\
\text { (Being merciful) }\end{array}$ & 3 & $\begin{array}{l}\text { Pagpaparaya } \\
\text { (tolerance) }\end{array}$ & 7 \\
\hline $\begin{array}{l}\text { Pagmumuni-muni } \\
\text { (Meditative reflection) }\end{array}$ & 6 & $\begin{array}{l}\text { Pagkamahinahon } \\
\text { (Being temperate) }\end{array}$ & 1 & $\begin{array}{l}\text { Pagpapalipas (Letting } \\
\text { it pass) }\end{array}$ & 3 \\
\hline $\begin{array}{l}\text { Pagninilay-nilay } \\
\text { (Mediation) }\end{array}$ & 4 & & & $\begin{array}{l}\text { Pagkukusa } \quad \text { (To } \\
\text { initiate) }\end{array}$ & 2 \\
\hline Paglimot (Forgetting) & 2 & & & $\begin{array}{l}\text { Pagdadala (carrying } \\
\text { the burden) }\end{array}$ & 2 \\
\hline $\begin{array}{l}\text { Positibong pag-iisip } \\
\text { (Positive thinking) }\end{array}$ & 1 & & & $\begin{array}{l}\text { Paghingi ng tawad } \\
\text { (Asking } \\
\text { forgiveness) }\end{array}$ & 1 \\
\hline $\begin{array}{l}\text { Pagpapakahulugan } \\
\text { (Meaning-making) }\end{array}$ & 1 & & & $\begin{array}{l}\text { Paglilinaw } \\
\text { (Clarifying) }\end{array}$ & 1 \\
\hline Kahulugan (Meaning) & 1 & & & $\begin{array}{l}\text { Pag-uusap (To talk } \\
\text { about) }\end{array}$ & 1 \\
\hline Pag-iisip (Thinking) & 1 & & & $\begin{array}{l}\text { Paglutas ng alitan (To } \\
\text { resolve a dispute) }\end{array}$ & 1 \\
\hline $\begin{array}{l}\text { Pagbigay kahulugan } \\
\text { (Giving meaning) }\end{array}$ & 1 & & & & \\
\hline
\end{tabular}


Rungduin, D. C. \& Rungduin, T. T.

Table 3 (continue ... )

\begin{tabular}{|c|c|c|c|}
\hline \multicolumn{2}{|l|}{ Individual } & \multicolumn{2}{|l|}{ cultural/social } \\
\hline Description & Frequency & Description & Frequency \\
\hline Pang-unawa (Understanding) & 25 & Ugnayan (Relationship) & 11 \\
\hline Pagtanggap (Acceptance) & 8 & Pagkarelihiyoso (Religiousity) & 11 \\
\hline Pagkamapagpahalaga & & Pakikipagkapwa (Deeper sense of & \\
\hline (Values) & 3 & relationship) & 7 \\
\hline Paniniwala (Personal Belief) & 2 & Panahon (Time) & 6 \\
\hline Karanasan (Exeprience) & 2 & Tradisyon (Tradition) & 2 \\
\hline Pagkalugod (Appreciation) & 2 & Pamilya (Family) & 2 \\
\hline Pagtitiwala (Trust) & 1 & Kapwa (Others) & 1 \\
\hline Pagtitimpi (Prudence) & 1 & Pagkakaibigan (Friendship) & 1 \\
\hline Pagkapalakaibigan & & & \\
\hline (Friendliness) & 1 & Pagmamalasakit (Concern for others) & 1 \\
\hline Mapagbigay (Sharing) & 1 & Pakikibagay (getting along with others) & 1 \\
\hline Mapagpahalaga (Putting & & Kinaugalian (to where one has been used & \\
\hline value on) & 1 & to) & 1 \\
\hline Mapagpatawad (Forgiving) & 1 & & \\
\hline Pagkatotoo (Being True) & 1 & & \\
\hline
\end{tabular}

Description of the Transgression. The studies suggest that transgressions generally reside in the violation of one's expectations in the performance of a role in social relationships. General descriptions that were found are being self-centered, not recognizing another's effort, and misjudging others. These behaviors consequently appear not to be subscribed by people who do not intend to transgress another individual. While many of them are relatively clear, the pananakit (hurting another) appeared to be a little vague. Pananakit (hurting another) could be inferred at the level of physical or emotional.

On the process of forgiving. The intention to forgive others appeared to be highly focused on the perception on the relationship with the transgressor. People who forgive tend to evaluate their relationship and the transgressor's behavior as positive, such as having hope for reconciliation and persistence to revive the relationship, respectively. On the other hand, they may also perceive the relationship and the transgressor's behavior negatively, such as avoiding the person or to be able to fight back against the transgressor. It is important to take note that this is highly crucial in deciding whether to forgive a transgressor or not. Primarily, more positive orientation towards the transgressor and his/her behavior can facilitate forgiveness and even to restore the relationship. The negative orientation, on other hand, can weaken the intention to continue the relationship, instead of relinquishing it.

Outcomes of forgiveness. When people are forgiving, it will lead to specific changes in the relationship with the transgressor. Noticeably forgiving another has been associated with positive outcomes both at the individual granting forgiveness (freedom from emotional burden and change within oneself) and in the relationship (restoration of relationship). Because people who have forgiven others become more positive in their orientation, they also become more welcoming with the changes that could happen within themselves or even with the relationship.

Contributory factors in forgiving others. Some mediating factors seem to surface in the studies that contribute to the propensity to forgive others. In arriving at forgiving others, the tripartite model (cognitive, affective, and behavioral components) was evident in the results. Although all of these mostly resides within the individual who is granting for forgiveness and not much on the person seeking for it, this is still important in the understanding of the dynamics of persons characteristics in forgiving others.

Cognitive component: open-mindedness and the ability to spend time to contemplate and reflect on the transgression. These characteristics implicate people who also have developed the interest to elaborate the 
behaviors of their transgressors. Through this process, intentions and details of behavior could possibly be clarified. It is important to take note that when a transgressed person has already closed his or her mind regarding other possibilities of understanding the transgressor, as opposed to being open-minded, it will result to blocking any possibilities of forgiving others.

Affective component: empathy and being calm. Empathy is important in the process of forgiving especially in determining the intention of the transgressor in doing the behavior and the forgiveness-seeking process. Without being empathic, the effort that an individual shows may be meaningless and there may be refusal to accommodate such behaviors. Because of empathy, the individual is also able to fully understand what happened using different perspectives.

Behavioral component: letting a transgression pass and manifestation of reconciliatory efforts from the transgression. This particular result pertains to the threshold of an individual to actually tolerate the transgressions. It is possible that there are transgressions that one could simply let pass while other transgressions require a greater amount of attention based on the amount of damages, either physical or psychological, to the individual. This characterization, however, may have implication in terms of how Filipinos viewed forgiveness. Pagpaparaya (sacrificing one's wants) and Pagpapalipas (letting time pass before deciding) being on the top observations may infer values of being less confrontative with the issue at hand, which may lead to forgetting the transgression.

\subsection{Emerging Filipino Values in Forgiveness}

The primary goal of this paper was to determine the Filipino values that surfaced from the literature of forgiveness. Primarily, the value system that was proposed of Enriquez was used in the identification of these values. While some of these values become highly evident, many of them also appeared to be not as useful in the forgiveness process. Consequently, the values were identified and clustered to form a model that will explain emerging values when one forgives.

\subsection{Enriquez's Value system}

In table 4, the frequency of occurrence of specific values can be seen under the different value categories that Enriquez identified. In each category, there seem to have one specific value that is highly evident compared with the others. Interpersonal value (Pakikiramdam). In the line-by-line analysis, pakikiramdam (shared inner perception) was one of the highest values that became highly evident. Pakikiramdam happens in forgiving others when the transgressed person tries to determine what the transgressor feels towards what happened (transgression). Also pakikiramdam is important in determining whether the transgressor's effort in seeking forgiveness is genuine or not. This could be an equivalent value of empathy in the earlier results presented. But pakikiramdam does not only entail to determine the genuineness of the forgiveness-seeking behavior of the transgressor but rather the over-all experience of granting forgiveness.

Pakikiramdam entails timing in terms of when one should approach the transgressed to seek for forgiveness and to evaluate if the strategy in seeking for forgiveness was effective or not. Without pakikiramdam, the attempt to seek for forgiveness could in fact heighten the negative emotion which could lead to worsening of the situation. This means that pakikiramdam is a value that is important to both person who are granting and seeking for forgiveness.

Accommodative values. Among the accommodative values, it was pakikisama (companionship) that became evident in the process of forgiving others compared with utang na loob and hiya. Pakikisama being a higher social value (i.e. people see this as a socially relevant) provides a grounding in facilitating the forgiveness process. Pakikisama actually strengthens the possibility of granting forgiveness due to the feeling of being compelled to do it. In the context of forgiveness, the pressure does not come from the people who are directly involved in the conflict but instead with other people who are not directly part of the transgression. This 
Rungduin, D. C. \& Rungduin, T. T.

highlights now the person's common relationship and the possibility of bringing the transgressed and the transgressor towards reconciliation.

\section{Table 4}

Values of Kapwa

\begin{tabular}{|c|c|c|c|}
\hline \multicolumn{2}{|c|}{ Kapwa-related values } & \multicolumn{2}{|c|}{ Loob-related values } \\
\hline Specific Values & frequency & Specific Values & Frequency \\
\hline Kalayaan (Freedom) & 38 & Kagandahang loob (Kindness) & 66 \\
\hline Katarungan (Justice) & 15 & Utang na loob (Depth of gratitude) & 19 \\
\hline Pagiging patas (Being fair) & 5 & Gaan ng loob (Lightness of mind) & 18 \\
\hline Hustisya (Justice) & 1 & Loob (State of mind) & 5 \\
\hline Makatao (Humane) & 1 & Bigat ng loob (Burdened mind) & 4 \\
\hline Makatarungan (Just) & 1 & Kababaang loob (Humbleness) & 3 \\
\hline $\begin{array}{l}\text { Makatuwiran } \\
\text { (Reasonable) }\end{array}$ & 1 & Hina ng loob (Pusillanimity) & 2 \\
\hline Karangalan (Dignity) & 4 & $\begin{array}{l}\text { Pagbabalik loob (Repentance) } \\
\text { Kalooban (Inner being) } \\
\text { Kusang loob (Initiative) } \\
\text { Tibay ng loob (Fortitude) }\end{array}$ & $\begin{array}{l}2 \\
1 \\
1 \\
1\end{array}$ \\
\hline
\end{tabular}

Table 5

Other related values

\begin{tabular}{|c|c|c|c|c|c|}
\hline \multicolumn{2}{|c|}{ Accommodative values } & \multicolumn{2}{|c|}{ Associated values } & \multicolumn{2}{|c|}{ Confrontative value } \\
\hline Specific Values & frequency & Specific Values & frequency & Specific Values & frequency \\
\hline $\begin{array}{l}\text { Pakikisama } \\
\text { (Companionship) }\end{array}$ & 77 & $\begin{array}{l}\text { Tampo (Affective } \\
\text { disappointment) }\end{array}$ & 36 & $\begin{array}{l}\text { Sama ng loob } \\
\text { (Resentment) }\end{array}$ & 101 \\
\hline $\begin{array}{l}\text { Utang na loob } \\
\text { (Depth of Gratitude) }\end{array}$ & 19 & $\begin{array}{l}\text { Lambing } \\
\text { (Sweetness) }\end{array}$ & 20 & $\begin{array}{l}\text { Pakikibaka } \\
\text { (Resistance) }\end{array}$ & 58 \\
\hline Hiya (Shame) & 12 & Biro (Joke) & 3 & $\begin{array}{l}\text { Bahala na } \\
\text { (Determination) }\end{array}$ & 10 \\
\hline & & & & $\begin{array}{l}\text { Lakas ng loob } \\
\text { (Guts) }\end{array}$ & 9 \\
\hline
\end{tabular}

Pakikisama, however, could have several implications in terms of granting forgiveness. First, there will be a question of whether the conflict has been actually resolved or not. When forgiveness is granted, there is a presumption that the transgression has been resolved. However, if pakikisama becomes the primary reason for conflict resolution, it is possible that the person did not resolve the issues that he/she has towards the person and instead saw the value to be significant in the relationship with other person/s who serve as links between the transgressor and the transgressed. This could possibly result to the earlier results which is letting the transgression pass (pagpaparaya). Because one is nakikisama (trying to get along with others), s/he could just let the transgression pass. Second, since pakikisama is a relationship-oriented value, the person's feeling may be disregarded and may not be given importance to. Transgressors could be very complacent about their actions without thinking so much of the offense that he or she has done to the other person. Lastly, due to pakikisama forgiveness could be forced. Especially those who highly value pakikisama, the person who are either granting or seeking forgiveness, may over simplify the process of forgiveness in such a manner that forgiveness-seeking behaviors may not anymore be valued.

Associated values. Among the associated values, tampo (affective disappointment) was the most evident value compared with lambing (sweetness) and biro (joke). In understanding forgiveness, it is imperative to 
understand where the transgression is coming from. Here, it is evident that because of tampo, forgiveness is needed. While one can argue that tampo is easier to resolve than galit (hatred), sama ng loob (resentment), and hinanakit (displeasure) it is still evident that even tampo requires forgiveness. This establishes an idea that forgiveness may not necessarily depend on the level of emotional pain that is inflicted instead on its essence. This result indicates that an action that has caused an offense, whether it is heavily loaded or not, actually requires forgiveness. It may be not the same as those that have caused deep emotional pain but tampo nevertheless made the person feel offended.

Confrontative values: Among the confrontative values, forgiveness is highly associated with sama ng loob (resentment) than values such as pakikibaka (resistance), bahala na (determination), and lakas ng loob (guts). People forgive because they have been offended by another person that caused them to feel bad about the situation, the transgressor, and the transgression. This also indicates the emotional sensitivity of Filipinos in their social relationships. When an offensive behavior is done against them, they rather take it at the emotional level rather than assert and assess their selves objectively. Also, this indicates that when assessing whether to forgive a transgression, the weight of the emotional burden is a major reference point than how they actually behaved during the conflict and towards the transgressor.

Aside from the surface values, there were also values that Enriquez identified related to the concept of Kapwa. These values were katarungan (justice), kalayaan (freedom), karangalan (dignity), and kagandahang loob (kindness). The first 3 were analyzed separate from the kagandahang-loob. The latter were included in the loob-related section. Nevertheless, katarungan, kalayaan, and kagandahang-loob become were highly evident in the analysis. It is only the karangalan that was not recovered in the analysis.

Kapwa-related values. In the analysis, two of the kapwa-related values surfaced; these are katarungan and kalayaan but not the karangalan. Table 5 presents the frequency of occurrence of these values. In terms of the katarungan, the transgressed individuals tend to highlight what is fair and just in the process of granting forgiveness in relation to what has been done to them. This could imply the before forgiveness is granted, there seem to have an assessment of the equivalence between what has been done (transgression) and the effort exerted by the transgressor in seeking for forgiveness. It only becomes makatarungan (just) when there is a sufficient equivalence between the two. This could explain the reason why, in some instances, people find it difficult to grant forgiveness. For them the consequence on the transgressor may not be congruent in relation to what has been done. The granting of forgiveness becomes more difficult, perhaps, when the transgressor enjoys pleasurable consequence directly related to the transgression behavior. This adds to the perception of injustice within the individual.

Kalayaan, on the other hand, was contextualized differently from the different forgiveness studies. While kalayaan was conceptualized as the capacity to make a choice independent from the influence of other people, kalayaan in the forgiveness studies was conceptualized as the freedom from emotional and cognitive burdens when they forgive. While the person is not forgiving, the person is burdened with negative emotions and thoughts which prevent him/her from fully appreciating other relationship and life opportunities. In the context of Valbuena's (2009) study, adapted the Decenteceo's concept of pagdadala, when one forgives, the dinadala (the emotional luggage being carried by an individual) become lighter while when one chooses not to forgive the heaviness of the dinadala remains to be there. Thus, kalayaan also connotes gaan ng loob.

Loob-related values. Forgiveness is an act of showing kagandahan ng loob. People who forgive tend to exercise such value towards other people. Other related concepts that came out were gaan ng loob, bigat ng loob, and kababaang loob. These become indicative of the positive attributes given to those people who are forgiving. This could be explained by those positive attributes that have been associated with the act of forgiving others, such as being an open-minded and being understanding of other's behavior. 


\section{Proposed value-based forgiveness model}

Highlighting the different values that emerged from the different studies on forgiveness, a proposed model is presented that places weight on the role of values in the decision to forgive others. The model provides both the structures and the process involve in forgiving others. Figure 1 illustrates the model generated from the results of the analysis.

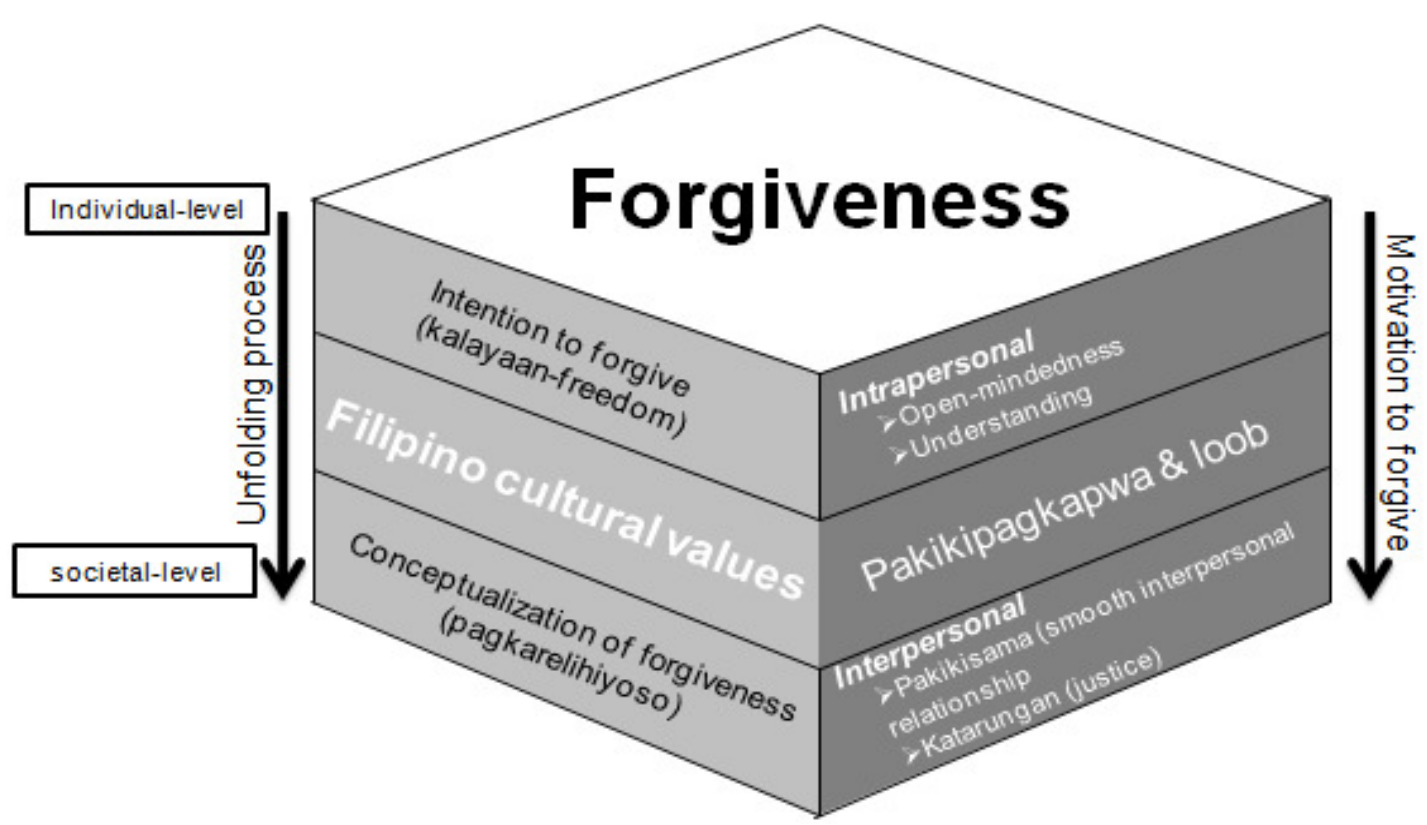

Figure 1. Proposed value-based forgiveness model

The arrival or conscious processing of forgiveness depends on the interaction of two factors namely, the motivation to forgive (right side of the cube) and the manner by which forgiveness unfolds (left side of the cube). These two factors are evaluated in the context of a continuum having the individual level at one side and societal level at the other side. The motivation to forgive a transgressor answers the why of forgiving while the unfolding process explains how people realize forgiveness. These two processes are supposed to be regulated by the cultural values observed at a particular group or individual, which in the context the Filipinos. Filipino values, particularly pakikipagkapwa and loob-related values (utang na loob and gaan ng loob) serve as factors that can reinforce or weaken the impact of the individual or societal dimension of forgiveness. This explains that people who do not feel the need to makipagkapwa-tao and/or the gaan $n g$ loob will lessen the motivation to forgive and consequently to actually forgive a transgressor.

The intention to forgive can be understood in two levels: intrapersonal and interpersonal. The intrapersonal motivation resides on the idea that particular characteristics lead the person toward forgiveness. Characteristics, such as open-mindedness and understanding were identified to become salient in this dimension. If these characteristics are highly observable, they are able to better understand the situation as well as the individual who have committed the transgression. These are considered important in order to change one's perspective about the transgression and be motivated to forgive. The motivation can also be due to interpersonal motivation. This means that people may place high regard with relationship with the transgressor or with people whom they both belong. These motivational factors become more important if the desire for smooth interpersonal and justice have been obtained. Smooth interpersonal relationship and justice function in an opposite direction when it comes to influencing the motivation to forgive. Clearly, a high need for smooth interpersonal relationship will amplify the need to forgive while the need for justice can delay forgiveness. When justice becomes the motivating factor, it will require a highly subjective evaluation on the transgressor's reconciliatory action and 
consequence. Hence, high standards of fairness and justice can be detrimental to forgiveness.

The realization of forgiving a transgressor will depend to how the two factors unfold within the individual. First, at the individual level, the person should have an intention to forgive the transgressor. Although intention is not the same with actually doing the behavior, it is imperative to assume that having the intention may the beginning of behaviors, like of forgiveness. Forgiveness may also come in the context of how it is shared by Filipinos. Religiosity appears to be a focal point by which people share common knowledge in defining forgiveness. Because of this common knowledge, it becomes a behavioral expectation whenever people are placed in transgressing situations. Filipinos being collectively religious tend to attribute their actions with their religious beliefs and teachings. Strong religious affinity, which teaches and promotes strong forgiveness behaviors, can be an important element in advancing the intention to forgive the person.

The unfolding process (left side of the model) maintains that a person goes through realizing how forgiving will facilitate being free from the burdens of the memory of the transgression and the memory of the transgressor being a person who hurts. There is the intention to forgive which from the analysis of the foregoing studies would be the first steps towards perceiving that the transgressor are doing acts that show repentance (perceived repentance as used by Tabbada-Rungduin, 2011). The second process would revolve around the integration of the values that are important to the person who forgives, these values are mostly culturally-based (i.e. kalayaan, gaan ng loob, kagandahang loob). The intention to forgive and the values prompt the person to see the weight of how forgiveness of the transgression and transgressor would add up to his or well-being or gaan ng loob. Lastly, the realization of the forgiveness process is facilitated by values that relevant institutions such as the family, school, community and the very evident church which implicates strong religious influences on choosing to forgive.

In the middle of the paradigm is a box focusing on the values. Somehow in the context of understanding forgiveness and in the process of giving it to the transgressor, one's values may be put into test. These values (e.g. pakikipagkapwa, kagandahang loob, and utang na loob) become essential in deciding whether to grant forgiveness or not. It is through the manifestation of values that the individual's internal mechanism of prioritizing his or her values (how he or she wants to continue the relationship) interact with society's meaning of forgiveness (e.g. reconciliation and/or religious affinity) may influence his or her capacity to forgive.

Given the value-based analysis, as mentioned in the earlier part of this paper, studies on values concerning forgiveness has been limited; the proposed model seeks to explain how forgiveness is first, seen from the perspective of Filipinos from all ages. Second, how the understanding of forgiveness are responsive to the challenge posed by Enriquez (Enriquez, 1994; Pe-Pua \& Protacio-Marcelino, 2000). Third, the model shows the unfolding processes of forgiveness from the individual to the societal level. The model proposed aims to facilitate other researchers who would like to further understand the various perspectives on forgiveness from an indigenous level and may be useful for educators who would like to integrate strengths of character in their curricula.

\subsection{Authors' note}

Filipino values were translated for the purpose of international readership. Filipino psychology strongly argues that many of the Filipino values lose their actual cultural and behavioral meanings when their lexical tags are changed. Specifically, those values that were identified by Enriquez, like pakikipagkapwa (deeper sense of relationship) and utang na loob (depth of gratitude), cannot be given an English equivalent because their conceptual, behavioral, and cultural meanings are to be examined. 


\section{Acknowledgement}

The authors would like to thank the following people who contributed to making this research possible, Dr. Maria Theresa Ujano-Batangan of the University of the Philippines-Diliman Department of Psychology whose insights provided depth to the model that emerged from the values analysis; and the experts who helped the researchers make sense of the word listings and provide a different perspective to what has already been explained.

\section{References}

Berry, J. W., Worthington, E. L., O'Connor, L. E., Parrott, L., \& Wade, N. G. (2005). Forgivingness, vengeful rumination, and affective traits. Journal of Personality, 73(1), 183-225. http://dx.doi.org/10.1111/j.1467-6494.2004.00308.x

Carr, K., \& Wang, T. R. (2012). Forgiveness isn't a simple process: It's a vast undertaking": Negotiating and communicating forgiveness in nonvoluntary family relationships. Journal of Family Communication, 12( 1), 40-56. http://dx.doi.org/10.1080/15267431.2011.629970

Chiaramello, S., Sastre, M. T., \& Mullet, E. (2008). Seeking forgiveness: Factor structure, and relationships with personality and forgivingness. Personality and Individual Differences, 45(5), 383-388. http://dx.doi.org/10.1016/j.paid.2008.05.009

De Castro, F. R. (2008). Effectiveness of a group forgiveness intervention on forgiveness and perceived stress of selected high school. Unpublished masteral thesis, University of Santo Tomas, Manila.

Enriquez, V. (1994). Pagbabagong-dangal: Indegenous psychology and cultural emporwerment. Quezon City: Akademya ng Sikolohiyang Pilipino [Academy of Filipino Psychology].

Enriquez, V. (1982). Filipinization of personality theory: towards the new awareness of the indigenous value structure. In R. Pe-Pua, Sikolohiyang Pilipino: Teorya, Metodo, at Gamit [Filipino Psychology: Theory, Method, and Use]. Quezon City: Akademya ng Sikolohiyang Pilipino [Academy of Filipino Psychology].

Enriquez, V. G. (1978). Kapwa: A core concept of Filipino Social Psychology. Philippine Social Sciences and Humanities Review, 42, 100-108.

Exline, J. J., Worthington, E. L., \& Mccullough, M. E. (2003). Forgiveness and Justice: A research agenda. Personality and Social Psychology Review, 7(4), 337-348. http://dx.doi.org/10.1207/S15327957PSPR0704_06

Fu, H., Watkins, D., \& Hui, E. K. (2004). Personality correlates of the disposition towards interpersonal forgiveness: A Chinese perspective. International Journal of Psychology, 39(4), 305-316. http://dx.doi.org/10.1080/00207590344000402

Gibbs, G. R. (2007). Analyzing Qualitative Data. London: SAGE Publications Ltd.

Ho, M. Y., \& Fung, H. H. (2011). A dynamic process model of forgiveness: A cross-cultural perspective. Review of General Psychology, 15(1), 77-84. http://dx.doi.org/10.1037/a0022605

Karremans, J. C., \& Van Lange, P. A. (2005). Does activating justice help or hurt in promoting forgiveness? Journal of Experimental Social Psychology, 41(3), 290-297. http://dx.doi.org/10.1016/j.jesp.2004.06.005

Klatt, J., \& Enright, R. (2009). Investigating the place of forgiveness within the Positive Youth Development paradigm. Journal of Moral Education, 38(1), 35-52. http://dx.doi.org/10.1080/03057240802601532

McCullough, M. E. (2001). Forgiveness: Who does it and how do they do it? Current Directions in Psychological Science, 10(6), 194-198.

McCullough, M. E., \& Witvliet, C. v. (2002). The psychology of forgiveness. In C. R. Snyde \& S. J. Lopez (Eds.), Handbook of positive psychology (pp. 446-458). New York: Oxford University Press.

Moustakas, C. (1994). Phenomenological research methods. Thousand Oaks, California: Sage Publications, Inc. Pan, S. (2008). Forgiveness in individualism and collectivism. Theological Forum, 52, 107-124.

Paz, R., Neto, F., Mullet, E. (2008). Forgiveness: A China-Western Europe comparison. The Journal of 
Psychology, 142(2), 147-157. http://dx.doi.org/10.3200/JRLP.142.2.147-158

Pe-Pua, R., \& Protacio-Marcelino, E. A. (2000). Sikolohiyang Pilipino [Filipino Psychology]: A legacy of Virgilio G. Enriquez. Asian Journal of Social Psychology, 3(1), 49-71. http://dx.doi.org/10.1111/1467-839X.00054

Rungduin, D. C. (2012). Contextual comparison on cognitive, affective, and behavioral dimensions of pagpapatawad [forgiveness] and pagpapalampas [letting pass]. Paper presented at the 49th PAP National Conference.

Sandage, S., \& Williamson, I. (2010). Relational spirituality and disposotional forgiveness: A structural equation model. Journal of Psychology and Theology, 38(4), 255-266.

Sandage, S. J., \& Worthington, E. L. (2010). Comparison of two group interventions to promote forgiveness: Empathy as a mediator of change. Journal of Mental Health Counseling, 32(1), 35-57.

Santos, H. C. (2012). Interpersonal motives and cultural values behind forgiveness: A study in the Philippines and in the United States. Unpublished masteral thesis, Georgetown University.

Strelan, P., \& Covic, T. (2006). A review of forgiveness process models and a coping framework to guide future research. Journal of Social and Clinical Psychology, 25(10), 1059-1085. http://dx.doi.org/10.1521/jscp.2006.25.10.1059

Tabbada-Rungduin, T. V. (2011). Ang paglalakbay tungo sa pagpapatawad: Isang debelopmental na perspektibo [The journey towards forgiveness: A developmental perspective]. Unpublished doctoral disseration, University of the Philippines, Quezon City.

Thompson, L. Y., Snyder, C. R., Hoffman, L., Michael, S. T., Rasmussen, H. N., . . Roberts, D. E. (2005). Dispositional forgiveness of self, others, and situations. Journal of Personality, 73(2), 313-359. http://dx.doi.org/10.1111/j.1467-6494.2005.00311.x

Toussaint, L., \& Webb, J. R. (2005). Gender differences in the relationship between empathy and forgiveness. Journal of Social Psychology, 145(6), 673-685. http://dx.doi.org/10.3200/SOCP.145.6.673-686

Valbuena, L. V. (2009). Pagpapatawad [forgiveness]: A descriptive study of the concept and its processes. Unpublished masteral thesis, University of the Philippines, .

Wenzel, M., \& Okimoto, T. G. (2010). How acts of forgiveness restore a sense of justice: Addressing status/power and value concerns raised by transgressions. European Journal of Social Psychology, 40, 401-417. http://dx.doi.org/10.1002/ejsp.629

Williamson, I., \& Gonzales, M. (2007). The subjective experience of forgiveness: Positive construals of the forgiveness experience. Journal of Social and Clinical Psychology, 26(4), 407-446. http://dx.doi.org/10.1521/jscp.2007.26.4.407

Worthington Jr., E. L., Everett L., Hunter, J. L., Sharp, C. B., Hook, J. N., Van Tongeren, D. R., Davis, D. E., Miller, A. J., Gingrich, F. C., Sandage, S. J., . . Monforte-Milton, M. (2010). A Psychoeducational Intervention to Promote Forgiveness in Christians in the Philippines. Journal of Mental Health Counseling, 32(1), 75-93.

Yabut, H. R. (2009). The phenomenology of forgiving another person. Philippine Journal of Counseling Psychology, 11, 104-122. 
Rungduin, D. C. \& Rungduin, T. T. 